\title{
UNIVERSITY OF BUCKINGHAM CENTRE FOR EXTRACTIVE ENERGY STUDIES (UBCEES)
}

The University of Buckingham Centre for Extractive Energy Studies (UBCEES) offers a uniquely holistic approach to the study of extractive energy. This ranges from issues of good governance and accountability, combating corruption and asset recovery, on to the legal, fiscal and competition issues relating to the actual process of the extraction and carriage of energy resources and its environmental and social impact. It also explores contemporary issues relating to the exploitation and extraction of offshore energy from the sea, fracking, community and labour rights in the global extractive energy sector, including indigenous community participation in the decision-making process of the ownership and the sustainable management of energy resources.

The Centre is led by Professor John Hatchard and Dr. Hephzibah Egede (Co-directors) in collaboration with Mr. Jae Sundaram who leads the Centre's Maritime unit. The Centre was launched on October 162013 and is guided by an Advisory Board which consists of leading academics and practitioners in the extractive energy sector. The Board provides expert guidance in the development and implementation of the programmes and activities of the Centre.

\section{Advisory Board Membership}

Current members of the UBCEES Advisory Board are:

I. Mr. Marc Hammerson, Chair, UBCEES Advisory Board, Partner, Akin Gump Strauss Hauer \& Feld LLP.

II. Prof. RG Lee, Head, Birmingham Law School, University of Birmingham.

III. Prof. William Nuttall, Professor of Energy, Open University;

Fellow, Hughes Hall, University of Cambridge.

IV. Prof. Peter Slinn, Notre Dame University, Joint General Editor, Law Reports of the Commonwealth.

V. Mr. David Salter, Senior Associate Fellow, School of Law, University of Warwick.

VI. Mr. James Maton, Partner, Cooley LLP. 


\section{UCBEES}

VII. Mr. Abimbola Ogunbanjo, Partner, Chris Ogunbanjo \& Co, First Vice President, Nigerian Stock Exchange.

\section{UBCEES Conferences}

Since its inception in 2013, the Centre has hosted a series of energy conferences which cover a wide range of topical issues concerning the global extractive energy sector.

I. "Current Legal and Policy Issues in the Global Energy Sector" (October 2013).

II. "Governance and Social Issues in the Extractive Energy Sector" (May 2014).

III. "Current Legal and Policy Issues in the African Energy Market" (October 2014)

IV. "Marine Life, Oil Spills, Shipping and Piracy: Contemporary Maritime Challenges in Offshore Energy Exploitation" (October 2015)

V. "Oil and Gas Decommissioning" (May 2016). This conference was facilitated and supported by Akin Gump Strauss Hauer \& Feld LLP and Globe Law Publishers.

\section{Forthcoming Conference}

The Centre in collaboration with the Open University will host a conference on "Nuclear Energy Law, Policy and Regulation" in the first quarter of 2017.

\section{UBCEES Energy Club}

The Centre has also established a Student Energy Club to encourage the discussion of and publication about contemporary energy issues. It provides the student community (undergraduate and postgraduate) with learning and networking opportunities preparatory to prospective careers in the energy sector. The President of the Student Energy Club, Ms. Grace AbakweAtsegwasi, a current doctoral student, was also given an opportunity to share highlights of her current doctoral thesis on offshore health, safety and environmental regulation in Nigeria at the recently concluded UBCEES conference on contemporary maritime challenges in offshore energy exploitation. 


\section{UCBEES}

\section{UBCEES Masterclasses}

One of the Centre's objectives is to further enhance and develop the teaching and research of extractive energy specialisms such as Oil and Gas Law at the Buckingham Law School. In furtherance of this objective, the UBCEES held its first Oil and Gas masterclass for those students taking the Oil and Gas Law course at the LLM level. The masterclass, which held on March $2^{\text {nd }} 2016$, was hosted at Akin Gump Strauss Hauer \& Feld LLP (a leading law firm consistently recognized for its practice in energy law). The masterclass was facilitated by three energy lawyers at Akin Gump and covered key areas in oil and gas such as host state contracts, licensing and energy disputes. The Centre plans to hold further practitioner led master classes to enhance student learning at the Buckingham Law School.

\section{UBCEES Contact Details}

Prof John Hatchard: john.hatchard@buckingham.ac.uk Dr. Hephzibah Egede: hephzibah.egede@buckingham.ac.uk 